\title{
An Engineering Learning Community To Promote Retention And Graduation Of At-Risk Engineering Students
}

Kenneth G. Ricks, University of Alabama, USA

James A. Richardson, University of Alabama, USA

Harold P. Stern, Texas State University, USA

Robert P. Taylor, University of Alabama, USA

Ryan A. Taylor, Mississippi State University, USA

\begin{abstract}
Retention and graduation rates for engineering disciplines are significantly lower than desired, and research literature offers many possible causes. Engineering learning communities provide the opportunity to study relationships among specific causes and to develop and evaluate activities designed to lessen their impact. This paper details an engineering learning community created to combat three common threats to academic success of engineering students: financial difficulties, math deficiencies, and the lack of a supportive engineering culture. The project tracks participants in the learning community from first year through graduation to assess the effectiveness of its activities in improving retention and graduation rates. Scholarships were made available to address the financial difficulties; tutors, mentors, study groups, and a "freshman-to-sophomore bridge" summer program were provided to address math deficiencies; cohort engineering courses, active learning techniques, required group meetings, required group study sessions, dedicated study space, and dedicated faculty advisors were used to promote a sense of community. Quantitative retention and graduation rates for the cohort are compared to other engineering groups at the same institution. Qualitative results collected via student surveys and interviews, and lessons learned by project administrators are also presented. Retention and graduation rates of the cohort are better than those of comparable groups at the same institution. Graduation rates based upon freshman math placement are also higher than comparable groups.
\end{abstract}

Keywords: At-Risk Engineering Students; Engineering Learning Community; Graduation Rate; Retention Rate

\section{INTRODUCTION}

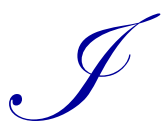

n 2006, nationally less than 55\% of students who began engineering studies actually completed an engineering degree program (Clough, 2006). Another source reports the 2007 average retention rate at U.S. engineering schools was just 56\%, and at some schools it was as low as $30 \%$ (Grose, 2012). Retention rates of underrepresented minorities in engineering can be significantly worse, as much as $20 \%$ lower for certain groups (H. Hartman \& M. Hartman, 2006). Although recent research suggests retention rates in engineering are comparable to those in other majors (Ohland et al., 2008) and that the gap in attrition rates between men and women in engineering has narrowed (Marra, Rodgers, Shen, \& Bogue, 2012; National Science Foundation [NSF], 2008), there is still concern especially considering the growing demand for graduates in engineering disciplines (Marra et al., 2012).

Educators and researchers have cited many possible reasons for retention problems for students in Science, Technology, Engineering, and Math (STEM) disciplines including: uninspiring introductory courses (Gates Jr. \& Mirkin, 2012), poor teaching and advising (Matthews, 2012), the difficulty of the curriculum (Lichtenstein, McCormick, Sheppard, \& Puma, 2010; Matthews, 2012), deficiencies in mathematics (Grimm, 2005; H. Hartman \& M. Hartman, 2006; Parker, 2005; Scalise, Bersterfield-Scare, Shuman, \& Wolfe, 2000), unsuccessful completion of 
first year math courses (Gilmer, 2007; Hanover Research, 2011; Herzog, 2003; Moore \& Shulock, 2009), lack of work ethic (H. Hartman \& M. Hartman, 2006), the so-called "chilly climate" within the engineering community (Gates Jr. \& Mirkin, 2012; H. Hartman \& M. Hartman, 2006; Marra et al., 2012; Matthews, 2012; Matusovich, Streveler, \& Miller, 2010; Seymour \& Hewitt, 1997), lack of "hands-on" projects (Knight, Carlson, \& Sullivan, 2003), financial difficulties (Grimm, 2005; Scalise et al., 2000; Veenstra, 2010), poor study habits (Grimm, 2005; Scalise et al., 2000), individual characteristics making some students less likely to persist (Litzler \& Young, 2012), and institutional characteristics (Tinto, 1975; Tinto, 2006) which are often considered as part of the "climate".

With improved persistence in STEM disciplines as the goal, many universities are offering programs to address the various reasons presented for lack of retention. Many institutions are establishing cohort learning communities specifically designed to address different aspects of this problem (Gates Jr. \& Mirkin, 2012; Gilmer, 2007; H. Hartman \& M. Hartman, 2006; Rutar \& Mason, 2005; Terenzini, Cabrera, Colbeck, Parente, \& Bjorklund, 2001; Zhao \& Kuh, 2004), and the successes of such communities are well documented (Zhao \& Kuh, 2004). Other initiatives include pre-college bridge programs to better prepare students for their first year (Gates Jr. \& Mirkin, 2012; Gilmer, 2007; Grimm, 2005), improved peer and faculty mentoring (Gilmer, 2007), increased undergraduate research opportunities (Gates Jr. \& Mirkin, 2012), and various active and collaborative learning initiatives (Knight et al., 2003; Rutar \& Mason, 2005; Terenzini et al., 2001).

Though not a new concept, learning communities have only gained broad recognition within the last 15-20 years. In general, learning communities consist of a group of students, connected via some common academic thread, who are offered opportunities for extracurricular interaction through common group activities and/or courses. Due to the shared experiences and common academic interests, participants often demonstrate increased levels of academic engagement, improved personal development, improved social awareness, stronger problem-solving skills, and increased levels of student learning (Zhao \& Kuh, 2004). Learning communities typically take one of four forms:

1) curricular learning communities where the student group, as a whole, is enrolled in two or more courses;

2) classroom learning communities where most group activities take place within the classroom and often involve various active and collaborative learning activities;

3) residential learning communities where the student group lives within close proximity of one another, often on-campus, providing more opportunities for social interaction;

4) student-type learning communities where all the student participants share common personal characteristics, such as members of underrepresented groups, honor students, engineering students, etc. (Zhao \& Kuh, 2004).

This paper describes a pilot project at the University of Alabama (UA) that was designed to address three of the significant threats to the academic success of engineering students: financial difficulties, math deficiencies, and a lack of sense of belonging to the engineering community which is often referred to as the "chilly climate" problem. The UA project was built upon well-documented techniques to address these areas of concern such as the establishment of a learning community, availability of scholarships, the use of bridge programs, the use of active and collaborative learning opportunities, and enhanced peer and faculty mentoring. The learning community established as part of this project can be classified as a combination of a curricular community, a classroom community, and a student-type learning community where the common student characteristics include financial need, below average preparation in mathematics, and interest in either Electrical and Computer Engineering (ECE) or Civil Engineering (CE) (Zhao \& Kuh, 2004). Participants in the learning community, hereafter referred to as the UA S-STEM program, were tracked from their first year through graduation, and the effectiveness of the cohort activities in improving retention and graduation rates is presented.

As mentioned previously, this project is designed to address three specific reasons for lack of persistence within engineering disciplines: financial problems, deficiencies in mathematics, and a lack of a supportive learning community within engineering. These specific causes were chosen due to their prevalence at UA as well as many other institutions. Like many other universities, UA accepts students from a wide range of backgrounds. The region from which many UA students are recruited includes a wide array of economic areas ranging from affluent school districts with excellent K-12 education to rural and inner-city areas that are economically depressed. Retention of 
students from the economically-depressed regions is heavily impacted by financial obstacles, and substandard high school preparation, especially in mathematics and the sciences, often prevents such students from qualifying for merit-based scholarships. Similarly, many institutions see engineering freshmen placed across a wide range of first semester mathematics courses. For freshmen who are not Calculus-ready, this presents many problems, especially for those who are more than one course removed from taking Calculus I. Finally, all universities with a large College of Engineering are faced with challenges to create a more inviting environment for engineering students, especially for those in underrepresented groups. The popularity of engineering learning communities attests to these challenges.

The original UA participants in the pilot program consisted of 12 freshmen in ECE and 12 freshmen in CE who enrolled at UA in the Fall 2007 semester. Continued participation was based upon participants meeting specified academic and project-related requirements after each semester. Replacements were selected from the pool of transfer applicants from State of Alabama community colleges. In this way, the UA S-STEM program could also provide support to transfer students, another at-risk group (Coston, Lord, \& Monell, 2013). In total, ten replacement students were selected during the 5.5 year program, resulting in 34 total participants. The final participant graduated from UA in December 2012.

Project results are meant to provide data reflecting the quality of the activities to promote persistence to graduation. Quantitative data is presented in the form of retention and graduation rates for the participants compared to peer groups. It is believed that comparison data to peer groups not offered the same benefits provides valuable insight to the effectiveness of the project. It is noted that the sample set for this pilot project is small, necessitated by the large financial commitment required to support the student group from the time they entered UA through graduation. However, while not conclusive, the quantitative results are encouraging and can be used when designing larger-scale projects. Finally, qualitative data from this project have resulted in the institutionalization of key ideas at a much larger scale and designed to benefit all entering freshman in the UA College of Engineering.

\section{PROGRAM IMPLEMENTATION SPECIFICS}

\section{A. Student Selection Process and Criteria}

\section{Scholastic Eligibility Requirements}

For the first year of the project, student participants were required to be entering freshmen who had met all scholastic requirements necessary for admission to UA and the UA College of Engineering including: high school GPA of at least 3.0 and a minimum math ACT score of 22. The ACT target score was chosen specifically to include participants who might not be Calculus-ready as entering freshmen.

\section{Financial Requirements}

Cost of Attendance (COA) for UA is established by university administrators using an estimated student budget for tuition, fees, books, meals, and parking (UA, 2014a). The Estimated Family Contribution (EFC) for a student was determined using the Free Application for Federal Student Aid (FAFSA) form (Federal Student Aid, 2014). The amount of financial need for a student was calculated by Equation 1.

$\mathrm{COA}-\mathrm{EFC}$

and any student with positive financial need according to this metric was considered eligible for the UA S-STEM program.

\section{Personal Requirements}

First year applicants were required to submit three letters of recommendation and to write a Statement of Academic Purpose describing their plans for college and post-college years. The letters of recommendation and the 
Statement of Academic Purpose were reviewed to assess each candidate's potential to contribute positively to the student cohort. There was no requirement that participants be State of Alabama residents. Continuing Eligibility Requirements

Each participant was assessed for continuing eligibility at the end of each semester. GPA and credit hour requirements are shown in Table 1. GPA and minimum course load requirements were established with the background of many of the participants in mind. The GPA requirements were based upon a 4.00 scale and pertain to on-campus GPA only. Transfer credit was not used in GPA calculations.

Table 1. Academic Requirements For Continuing Eligibility

\begin{tabular}{|c|c|c|}
\hline & GPA & Minim um Course Load \\
\hline Freshman & 2.00 & 12 hours/semester \\
\hline Sophomore & 2.25 & 12 hours/semester \\
\hline Junior & 2.50 & 12 hours/semester \\
\hline Senior & 2.50 & 12 hours/semester \\
\hline
\end{tabular}

In addition to these academic requirements, participants had to remain as either ECE or CE majors and be a contributing member of the cohort. For each semester, all participants were assigned a project status: good standing or warning. A status of good standing meant that all academic and project-related requirements were met for the previous semester. The warning status meant that one or more requirements were not met. Those on warning were given specific requirements to meet by the end of the subsequent semester. These requirements were customized to the individual student. For example, in some cases specific GPA requirements were provided. In other cases, specific course loads were required. Exceptions to the GPA and course load thresholds stated in Table 1 were allowed only if students were making progress to eliminate the deficiencies. If individual requirements were met, students could continue in the program. If not met, the student was dropped from the program. In this way, students were given an opportunity to correct any shortfalls before being dropped.

\section{Replacement Students}

Attrition of participants occurred both voluntarily and involuntarily. For those students who voluntarily left the program, it was almost always due to a change in major field of study. However, most attrition occurred involuntarily when students were dropped from the program by administrators due to not maintaining the continuing eligibility requirements as stated above. Due to attrition among the original 24 participants, replacements were selected from the pool of transfer applicants from State of Alabama community colleges. In this way, the UA SSTEM program could also provide scholarships and support activities to transfer students, another at-risk group that is often overlooked for such opportunities (Coston et al., 2013). Four replacements entered the program in Fall 2008. Six more entered the program in Fall 2009. Replacements were only invited into the program in Fall semesters to coincide with the beginning of an academic year. Beginning in Fall 2010, it was believed that new members would be difficult to integrate into the cohort considering some of the original students were entering their fourth year and nearing graduation. Also, there was concern that introduction of new members eroded the benefits of the cohort. Therefore, no new members were invited after the Fall 2009 semester. In total, ten replacement students were invited to join the program, resulting in 34 total participants. All participants were evaluated for continuing eligibility using the same metrics regardless of when they joined the program.

\section{B. Project Activities and Support Services}

\section{Financial Support}

As stated earlier, scholarships were made available to all participants to help address financial concerns related to attending college. Table 2 shows scholarship amounts available to participants. All scholarships were provided by the National Science Foundation (NSF) Scholarships in Science, Technology, Engineering and Math (S-STEM) program (NSF S-STEM, 2014). Scholarship amounts increased throughout the project period to offset some of the costs of rising tuition over this period. Scholarships were awarded on a per-semester basis, with status 
reviews occurring before each semester to determine continuing eligibility. Over the life of the project, $\$ 486,600$ was allocated for scholarships for the 34 participants.

Table 2. Scholarship Amounts By Academic Year

\begin{tabular}{|c|c|}
\hline Academ ic Year & Scholarship Am ount \\
\hline $2007-2008$ & $\$ 2000 /$ semester \\
\hline $2008-2009$ & $\$ 2500 /$ semester \\
\hline $2009-2010$ & $\$ 2500 /$ semester \\
\hline $2010-2011$ & $\$ 3500 /$ semester \\
\hline $2011-2012$ & $\$ 3500 /$ semester \\
\hline $2012-2013^{*}$ & $\$ 3666 /$ semester \\
\hline${ }^{*}$ Fall 2012 only & \\
\hline
\end{tabular}

\section{Mathematics Support Activities}

At many universities, entering freshmen engineering students are typically placed in a wide range of first semester math courses. For those placed in high-level math courses such as Calculus I or higher, they are either on schedule or ahead of the mathematics sequence, since it is typical for curricula in engineering disciplines to start with Calculus I in the first semester of the freshman year. Students not Calculus-ready may have to take one to three courses to prepare them just to start the mathematics sequence. Some universities prevent such students from being admitted to engineering, and some engineering learning communities only admit students at most one course away from Calculus (Gilmer, 2007). For those programs such as UA that have no such limits, this broader range of starting math courses represents an extra burden making it more difficult to retain students. The longer it takes students to become Calculus-ready, the more difficult it is to keep them in the discipline because prerequisite dependencies among courses often make it impossible to find hours that will count toward the degree if a student is not in Calculus I by their second semester. Until these students get through Calculus I, they often have to take courses that do not count toward their degree just to remain as full-time students. For those students in this situation and with financial limitations, they cannot afford to take courses that do not count toward the degree and often solve this problem by changing majors so they are no longer delayed by the Calculus sequence.

Table 3 shows the starting math courses for the 24 original UA S-STEM participants. Participants were preassessed and placed in a starting math course using their score on the standardized mathematics placement test used by UA for all entering freshmen. As shown in Table 3, only six of 24, or 25\%, entered UA Calculus-ready, and 11 of the 24 required at least two courses before taking Calculus I. The percentage of students in the UA S-STEM program that are not Calculus-ready is higher than that of typical UA freshman cohorts as shown in Table 4 where this data is presented for general freshman engineering cohorts and for CE and ECE freshman cohorts. However, this higher percentage was by design to assess the effectiveness of the project for at-risk students.

Table 3. Starting Mathematics Courses For Original UA S-STEM Participants

\begin{tabular}{|l|c|c|c|}
\hline \multicolumn{1}{|c|}{ Starting Math Course } & $\#$ & $\%$ & \# of Bridge Participants \\
\hline Calculus I or Higher & 6 & $25.00 \%$ & 1 \\
\hline 1 Course Below Calculus I & 7 & $29.17 \%$ & 3 \\
\hline 2 Courses Below Calculus I & 8 & $33.33 \%$ & 2 \\
\hline 3 Courses Below Calculus I (remedial math) & 3 & $12.50 \%$ & 0 \\
\hline \multicolumn{1}{r|r|}{ Total } & 24 & $100.00 \%$ & 6 \\
\hline All Transfer Students Started in Calculus II or Higher & & & \\
\hline
\end{tabular}


Table 4. Starting Math Courses For Each Freshman Cohort From 2001-2007 (UA, 2014c)

\begin{tabular}{|c|c|c|c|c|c|c|c|}
\hline \multirow{2}{*}{ Year } & \multirow{2}{*}{ Starting Math Course } & \multicolumn{2}{|c|}{ Engineering } & \multicolumn{2}{|c|}{ CE } & \multicolumn{2}{|c|}{ ECE } \\
\hline & & $\#$ & $\%$ & $\#$ & $\%$ & $\#$ & $\%$ \\
\hline \multirow[t]{3}{*}{2001} & Calculus I or Higher & 102 & $36.04 \%$ & 14 & $36.84 \%$ & 6 & $17.65 \%$ \\
\hline & Below Calculus I & 181 & $63.96 \%$ & 24 & $63.16 \%$ & 28 & $82.35 \%$ \\
\hline & Total & 283 & & 38 & & 34 & \\
\hline \multirow[t]{3}{*}{2002} & Calculus I or Higher & 132 & $40.87 \%$ & 15 & $36.59 \%$ & 13 & $36.11 \%$ \\
\hline & Below Calculus I & 191 & $59.13 \%$ & 26 & $63.41 \%$ & 23 & $63.89 \%$ \\
\hline & Total & 323 & & 41 & & 36 & \\
\hline \multirow[t]{3}{*}{2003} & "Calculus I or Higher & 122 & $37.77 \%$ & 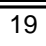 & $33.93 \%$ & 13 & $28.26 \%$ \\
\hline & Below Calculus I & 201 & $62.23 \%$ & 37 & $66.07 \%$ & 33 & $71.74 \%$ \\
\hline & Total & 323 & & 56 & & 46 & \\
\hline \multirow[t]{3}{*}{2004} & Calculus I or Higher & 152 & $42.70 \%$ & 19 & $38.00 \%$ & 28 & $48.28 \%$ \\
\hline & Below Calculus I & 204 & $57.30 \%$ & 31 & $62.00 \%$ & 30 & $51.72 \%$ \\
\hline & Total & 356 & & 50 & & 58 & \\
\hline \multirow[t]{3}{*}{2005} & Calculus I or Higher & 156 & $39.90 \%$ & 12 & $25.53 \%$ & 23 & $43.40 \%$ \\
\hline & Below Calculus I & 235 & $60.10 \%$ & 35 & $74.47 \%$ & 30 & $56.60 \%$ \\
\hline & Total & 391 & & 47 & & 53 & \\
\hline \multirow[t]{3}{*}{2006} & Calculus I or Higher & 275 & $54.46 \%$ & 32 & $39.02 \%$ & 31 & $63.27 \%$ \\
\hline & Below Calculus I & 230 & $45.54 \%$ & 50 & $60.98 \%$ & 18 & $36.73 \%$ \\
\hline & Total & 505 & & 82 & & 49 & \\
\hline \multirow[t]{3}{*}{2007} & Calculus I or Higher & 246 & $50.51 \%$ & 31 & $34.07 \%$ & 34 & $499.28 \%$ \\
\hline & Below Calculus I & 241 & $49.49 \%$ & 60 & $65.93 \%$ & 35 & $50.72 \%$ \\
\hline & Total & 487 & & 91 & & 69 & \\
\hline
\end{tabular}

To help students regarding math deficiencies, weekly peer study sessions were established during the first year of the project. Those participants in Calculus were asked to serve as tutors for the other students. This way, participants in the cohort began to establish strong relationships within the group, and those with strong study skills could advise others, thus taking on a mentoring role. Also, top performing engineering graduate and upper-level undergraduate students were hired to serve as additional mentors and tutors for all participants. Ad hoc training was provided to all tutors/mentors by project administrators, and informal interactions among tutors/mentors and participants were encouraged. Tutoring and mentoring was not limited to but did focus on mathematics courses.

The UA S-STEM program also established a "freshman-to-sophomore bridge" to help students who did not enter as Calculus-ready to "catch-up" in the math courses. Specifically, scholarships were provided to students to take math courses during the summer after the freshman year. Scholarships were only available to those students taking a math course during the summer term. A total of six students took advantage of the summer bridge program, only one of those entered the program as Calculus-ready. One positive result of the "freshman-to-sophomore bridge" was to reduce the mathematics differential between students within the cohort. This strengthened the cohort making it easier for students to form study groups and making it more likely that students within the group could register for the same courses in subsequent semesters.

\section{Community Building Activities}

The significance of the "climate" in engineering disciplines to student retention cannot be overstated (Lichtenstein et al., 2010; Marra et al., 2012). This is especially the case for women and other underrepresented populations in engineering (Litzler \& Young, 2012). Therefore, several activities were used to promote a sense of community within the cohort. Most of these activities were structured during year one only with the hopes that relationships and habits established in year one would allow students to independently continue similar activities in subsequent years. This first year approach is consistent with research that indicates the first year in an engineering 
program is crucial for long term persistence in the discipline (Besterfield-Sacre, Atman, \& Shuman, 1997; Marra et al., 2012).

The UA learning community established as part of this project was designed to incorporate components from three types of learning communities: curricular communities, classroom communities, and student-type communities (Zhao \& Kuh, 2004). The student-type aspects were established based upon the characteristics of the participants and were discussed previously. During the first year, all participants were registered in the same sections of several freshman engineering courses, thus establishing a curricular learning community (Zhao \& Kuh, 2004). These courses are generic, introductory-level courses required of all engineering freshmen at UA. To incorporate a classroom community component, active learning techniques were employed within these freshman courses to give students a more "user-friendly" and experimental introduction to the discipline (Zhao \& Kuh, 2004). These techniques included hands-on projects and group field trips to engineering sites. Particular attention was given to projects and sites having a social and/or environmental aspect since these are areas that often interest a broad range of student groups from different disciplines, including underrepresented groups. For example, students visited local water treatment facilities and then were asked to design and build prototype water treatment systems. Emphasis was placed on environmentally-friendly water treatment approaches. After the first year, students were encouraged to register for the same courses when possible. However, diverging curricula made it impossible to formalize this as a requirement for the entire group.

Also during the first year, the cohort was required to attend a weekly study session led by a faculty member either in ECE or CE. During this two-hour time period, students were encouraged to break into study groups and tutors were available. Emphasis was placed on mathematics courses; however, any course could be studied. The cohort had access to a dedicated study room with computers and a printer. This space was not advertised as a "lounge". Instead, students were encouraged to use the space for group meetings and study sessions. Also, mentoring among members of the cohort was encouraged, and the graduate and undergraduate tutors also served as mentors and promoted use of the space as a study room.

Each Fall semester, the cohort was required to attend a project "status" meeting. During this meeting, special time was given to introduce the new students and to attempt to integrate them into the existing group. This was especially important considering that new members missed all of the team-building activities during the first year of the project and considering that transfer students often feel alienated from the rest of the student population at their new institution (Coston et al., 2013).

For the entire duration of the project, students were advised each semester by a faculty member in ECE or CE. Advising took the form of mentoring, professional/career advising, and academic advising. For the latter, faculty advisors reviewed students' progress toward a degree, determined whether students met all project requirements for continuing eligibility, and helped students plan for future courses.

\section{STUDENT PERFORMANCE AND PROJECT RESULTS}

\section{A. Quantitative Results}

\section{Retention Rates}

Table 5 shows the retention data of the 34 participants of the UA S-STEM program. In this case, "retention" means these students persisted in either ECE or CE at UA and maintained their eligibility for the UA SSTEM program. In the bottom portion of Table 5, retention data for UA engineering freshmen cohorts, engineering transfer cohorts, and overall combined engineering cohorts (freshmen and transfers) from $2001-2007$ are presented for comparison (UA, 2014d; UA, 2014e). It should be noted that "retention" for the comparison UA engineering cohorts specifically means that students began and continued within an engineering discipline, but not necessarily the same engineering discipline. Therefore, the retention requirements of the UA S-STEM cohort are more restrictive than those for UA engineering cohorts in general. 
Table 5. Retention Rates Compared To Other UA Engineering Cohorts (UA, 2014d; UA, 2014e)

\begin{tabular}{|c|c|c|c|c|c|c|}
\hline & $\begin{array}{c}\text { \# of } \\
\text { Participants }\end{array}$ & $\begin{array}{c}\text { Continued } \\
\text { Year 2 }\end{array}$ & $\begin{array}{c}\text { Continued } \\
\text { Year 3 }\end{array}$ & $\begin{array}{c}\text { Continued } \\
\text { Year 4 }\end{array}$ & $\begin{array}{c}\text { Continued } \\
\text { Year 5 }\end{array}$ & $\begin{array}{c}\text { Continued } \\
\text { Year 6 }\end{array}$ \\
\hline $\begin{array}{c}\text { Original S-STEM } \\
\text { Freshman Cohort }\end{array}$ & 24 & 20 & 15 & 12 & 7 & 1 \\
\hline & & $83.3 \%$ & $62.5 \%$ & $50.0 \%$ & $29.2 \%$ & $4.2 \%$ \\
\hline \hline Transfer Students & 10 & 6 & 4 & 2 & 0 & 0 \\
\hline \hline & & $60.0 \%$ & $40.0 \%$ & $20.0 \%$ & $0.0 \%$ & $0.0 \%$ \\
\hline Overall & 34 & 26 & 19 & 14 & 7 & 1 \\
\hline
\end{tabular}

\begin{tabular}{|c|c|c|c|c|c|c|c|}
\hline $\begin{array}{l}\text { UA Engineering } \\
\text { Freshman } \\
\text { Cohorts }\end{array}$ & $\begin{array}{c}\text { \# of } \\
\text { Participants }\end{array}$ & $\begin{array}{c}\text { Continued } \\
\text { Year } 2\end{array}$ & $\begin{array}{c}\text { Continued } \\
\text { Year } 3\end{array}$ & $\begin{array}{c}\text { Continued } \\
\text { Year } 4\end{array}$ & $\begin{array}{c}\text { Continued } \\
\text { Year } 5\end{array}$ & $\begin{array}{c}\text { Continued } \\
\text { Year } 6\end{array}$ & \\
\hline 2001 & 283 & $67.0 \%$ & $49.5 \%$ & $41.6 \%$ & $26.2 \%$ & $7.9 \%$ & \\
\hline 2002 & 323 & $71.2 \%$ & $53.5 \%$ & $48.4 \%$ & $36.5 \%$ & $14.1 \%$ & \\
\hline 2003 & 323 & $77.3 \%$ & $59.7 \%$ & $51.8 \%$ & $38.0 \%$ & $11.2 \%$ & \\
\hline 2004 & 356 & $72.7 \%$ & $55.1 \%$ & $47.2 \%$ & $33.2 \%$ & $9.7 \%$ & \\
\hline 2005 & 391 & $73.3 \%$ & $55.8 \%$ & $46.6 \%$ & $28.5 \%$ & $7.9 \%$ & \\
\hline 2006 & 505 & $77.0 \%$ & $57.1 \%$ & $47.2 \%$ & $27.8 \%$ & $6.3 \%$ & \\
\hline \multirow[t]{2}{*}{2007} & 487 & $74.6 \%$ & $55.7 \%$ & $50.0 \%$ & $29.2 \%$ & $8.4 \%$ & \\
\hline & 381.1 & $73.3 \%$ & $55.2 \%$ & $47.5 \%$ & $31.3 \%$ & $9.4 \%$ & Average \\
\hline $\begin{array}{l}\text { UA Engineering } \\
\text { Transfer } \\
\text { Cohorts } \\
\end{array}$ & $\begin{array}{c}\text { \# of } \\
\text { Participants }\end{array}$ & $\begin{array}{c}\text { Continued } \\
\text { Year } 2\end{array}$ & $\begin{array}{c}\text { Continued } \\
\text { Year } 3\end{array}$ & $\begin{array}{c}\text { Continued } \\
\text { Year } 4\end{array}$ & $\begin{array}{c}\text { Continued } \\
\text { Year } 5\end{array}$ & $\begin{array}{c}\text { Continued } \\
\text { Year } 6\end{array}$ & \\
\hline 2001 & 123 & $70.7 \%$ & $59.3 \%$ & $36.6 \%$ & $11.4 \%$ & $4.1 \%$ & \\
\hline 2002 & 77 & $63.6 \%$ & $57.1 \%$ & $39.0 \%$ & $15.6 \%$ & $6.5 \%$ & \\
\hline 2003 & 99 & $60.6 \%$ & $50.5 \%$ & $38.4 \%$ & $11.1 \%$ & $4.0 \%$ & \\
\hline 2004 & 107 & $61.7 \%$ & $57.9 \%$ & $31.8 \%$ & $15.9 \%$ & $2.8 \%$ & \\
\hline 2005 & 96 & $59.4 \%$ & $47.9 \%$ & $29.2 \%$ & $16.7 \%$ & $2.1 \%$ & \\
\hline 2006 & 114 & $71.1 \%$ & $51.8 \%$ & $29.8 \%$ & $13.2 \%$ & $4.4 \%$ & \\
\hline \multirow[t]{2}{*}{2007} & 112 & $62.5 \%$ & $52.7 \%$ & $33.9 \%$ & $14.3 \%$ & $2.7 \%$ & \\
\hline & 104.0 & $64.2 \%$ & $53.9 \%$ & $34.1 \%$ & $14.0 \%$ & $3.8 \%$ & Average \\
\hline $\begin{array}{l}\text { Overall UA } \\
\text { Engineering } \\
\text { Cohorts }\end{array}$ & $\begin{array}{c}\text { \# of } \\
\text { Participants }\end{array}$ & $\begin{array}{c}\text { Continued } \\
\text { Year } 2\end{array}$ & $\begin{array}{c}\text { Continued } \\
\text { Year } 3\end{array}$ & $\begin{array}{c}\text { Continued } \\
\text { Year } 4\end{array}$ & $\begin{array}{c}\text { Continued } \\
\text { Year } 5\end{array}$ & $\begin{array}{c}\text { Continued } \\
\text { Year } 6\end{array}$ & \\
\hline 2001 & 406 & $68.2 \%$ & $52.5 \%$ & $38.7 \%$ & $21.7 \%$ & $6.7 \%$ & \\
\hline 2002 & 400 & $69.8 \%$ & $54.3 \%$ & $46.5 \%$ & $32.5 \%$ & $12.8 \%$ & \\
\hline 2003 & 422 & $73.5 \%$ & $57.3 \%$ & $48.3 \%$ & $31.8 \%$ & $7.1 \%$ & \\
\hline 2004 & 463 & $70.2 \%$ & $55.7 \%$ & $43.6 \%$ & $29.2 \%$ & $8.2 \%$ & \\
\hline 2005 & 487 & $70.6 \%$ & $54.2 \%$ & $43.1 \%$ & $26.1 \%$ & $6.8 \%$ & \\
\hline 2006 & 619 & $75.9 \%$ & $56.1 \%$ & $43.9 \%$ & $25.0 \%$ & $6.0 \%$ & \\
\hline \multirow[t]{2}{*}{2007} & 599 & $72.3 \%$ & $55.6 \%$ & $47.1 \%$ & $26.4 \%$ & $7.3 \%$ & \\
\hline & 485.1 & $71.5 \%$ & $55.1 \%$ & $44.5 \%$ & $27.5 \%$ & $7.8 \%$ & Average \\
\hline
\end{tabular}


The retention rates for the freshmen UA S-STEM participants are higher in years two, three, and four compared to that for UA freshmen engineering cohorts, significantly higher in years two and three. The retention numbers for transfer students and the combined numbers also indicate that the UA S-STEM participants did as well or better than their non-S-STEM counterparts. It should be noted that retention rates for years four and five can be deceptive. Graduates who complete their program of study in four years are not available to continue to years five and six. Therefore, lower retention rates in the latter years of the program are not necessarily a bad thing.

\section{Graduation Rates}

The top portion of Table 6 shows the graduation data of the 34 participants of the UA S-STEM program. In this case, "graduation" means these students persisted in either ECE or CE at UA and maintained their eligibility for the UA S-STEM program through their graduation. In the bottom portions of Table 6, graduation rates for UA engineering freshmen cohorts, engineering transfer cohorts, and overall combined engineering cohorts (freshmen and transfers) from 2001 - 2007 are presented for comparison (UA, 2014d; UA, 2014e). For the comparison cohorts, "graduation" means that these students entered UA in some engineering discipline and graduated with a B.S. in any engineering discipline at UA, and includes those students who changed disciplines within engineering.

The graduation rates for the original UA S-STEM freshman cohort are higher than those for UA freshmen engineering cohorts in most cases, even though the UA S-STEM students were held to a more restrictive environment, i.e. they had to remain in either ECE or CE and they had to meet all continuing eligibility requirements for the UA S-STEM program. The UA S-STEM transfer participant graduation rates and the graduation rates for the combined UA S-STEM group are comparable to or higher than their non-S-STEM counterparts in most cases.

Finally, it should also be noted that many of the UA S-STEM students participated in the Cooperative Education (CO-OP) Program. This internship-type program requires students to alternate between a work assignment and school until a minimum of three work terms is completed. The graduation for CO-OP participants was obviously delayed due to their work assignments and is the reason that graduation rates were tracked over a sixyear period. 
Table 6. Graduation Rates Compared To Other UA Engineering Cohorts (UA, 2014d; UA, 2014e)

\begin{tabular}{|c|c|c|c|c|c|c|}
\hline & $\begin{array}{c}\text { \# of } \\
\text { Participants }\end{array}$ & $\begin{array}{c}\text { Graduated in } \\
2 \text { or Fewer } \\
\text { Years }\end{array}$ & $\begin{array}{c}\text { Graduated in } \\
3 \text { or Fewer } \\
\text { Years }\end{array}$ & $\begin{array}{c}\text { Graduated in } \\
4 \text { or Fewer } \\
\text { Years }\end{array}$ & $\begin{array}{c}\text { Graduated in } \\
5 \text { or Fewer } \\
\text { Years }\end{array}$ & $\begin{array}{c}\text { Graduated in } \\
6 \text { or Fewer } \\
\text { Years }\end{array}$ \\
\hline \multirow[t]{2}{*}{$\begin{array}{l}\text { Original S-STEM } \\
\text { Freshman Cohort }\end{array}$} & 24 & 0 & 0 & 4 & 10 & 11 \\
\hline & & $0.0 \%$ & $0.0 \%$ & $16.7 \%$ & $41.7 \%$ & $45.8 \%$ \\
\hline \multirow[t]{2}{*}{ Transfer Students } & 10 & 0 & 1 & 3 & 3 & 3 \\
\hline & & $0.0 \%$ & $10.0 \%$ & $30.0 \%$ & $30.0 \%$ & $30.0 \%$ \\
\hline \multirow[t]{2}{*}{ Overall } & 34 & 0 & 1 & 7 & 13 & 14 \\
\hline & & $0.0 \%$ & $2.9 \%$ & $20.6 \%$ & $38.2 \%$ & $41.2 \%$ \\
\hline
\end{tabular}

\begin{tabular}{|c|c|c|c|c|c|c|}
\hline $\begin{array}{c}\text { UA Engineering } \\
\text { Freshman } \\
\text { Cohorts }\end{array}$ & $\begin{array}{c}\text { \# of } \\
\text { Participants }\end{array}$ & $\begin{array}{c}\text { Graduated in } \\
\text { 2 or Fewer } \\
\text { Years }\end{array}$ & $\begin{array}{c}\text { Graduated in } \\
\text { 3 or Fewer } \\
\text { Years }\end{array}$ & $\begin{array}{c}\text { Graduated in } \\
\mathbf{4} \text { or Fewer } \\
\text { Years }\end{array}$ & $\begin{array}{c}\text { Graduated in } \\
\mathbf{5} \text { or Few er } \\
\text { Years }\end{array}$ & $\begin{array}{c}\text { Graduated in } \\
\mathbf{6} \text { or Fewer } \\
\text { Years }\end{array}$ \\
\hline 2001 & 283 & $0.0 \%$ & $0.0 \%$ & $11.1 \%$ & $28.0 \%$ & $33.3 \%$ \\
\hline 2002 & 323 & $0.0 \%$ & $0.3 \%$ & $9.9 \%$ & $30.4 \%$ & $38.8 \%$ \\
\hline 2003 & 323 & $0.0 \%$ & $0.0 \%$ & $10.9 \%$ & $34.8 \%$ & $42.2 \%$ \\
\hline 2004 & 356 & $0.0 \%$ & $0.3 \%$ & $10.8 \%$ & $31.8 \%$ & $39.8 \%$ \\
\hline 2005 & 391 & $0.0 \%$ & $0.5 \%$ & $14.4 \%$ & $33.8 \%$ & $40.1 \%$ \\
\hline 2006 & 505 & $0.0 \%$ & $0.6 \%$ & $16.3 \%$ & $36.7 \%$ & $40.5 \%$ \\
\hline 2007 & 487 & $0.0 \%$ & $0.0 \%$ & $17.9 \%$ & $37.0 \%$ & $42.4 \%$ \\
\hline
\end{tabular}

\begin{tabular}{|c|c|c|c|c|c|c|}
\hline $\begin{array}{c}\text { UA Engineering } \\
\text { Transfer } \\
\text { Cohorts }\end{array}$ & $\begin{array}{c}\text { \# of } \\
\text { Participants }\end{array}$ & $\begin{array}{c}\text { Graduated in } \\
\text { 2 or Fewer } \\
\text { Years }\end{array}$ & $\begin{array}{c}\text { Graduated in } \\
\text { 3 or Fewer } \\
\text { Years }\end{array}$ & $\begin{array}{c}\text { Graduated in } \\
\text { 4 or Fewer } \\
\text { Years }\end{array}$ & $\begin{array}{c}\text { Graduated in } \\
\mathbf{5} \text { or Fewer } \\
\text { Years }\end{array}$ & $\begin{array}{c}\text { Graduated in } \\
\mathbf{6} \text { or Fewer } \\
\text { Years }\end{array}$ \\
\hline 2001 & 123 & $3.3 \%$ & $21.1 \%$ & $46.3 \%$ & $53.7 \%$ & $56.1 \%$ \\
\hline 2002 & 77 & $0.0 \%$ & $13.0 \%$ & $31.2 \%$ & $39.0 \%$ & $42.9 \%$ \\
\hline 2003 & 99 & $3.0 \%$ & $15.2 \%$ & $35.4 \%$ & $39.4 \%$ & $42.4 \%$ \\
\hline 2004 & 107 & $1.9 \%$ & $17.8 \%$ & $31.8 \%$ & $43.9 \%$ & $45.8 \%$ \\
\hline 2005 & 96 & $3.1 \%$ & $14.6 \%$ & $25.0 \%$ & $33.3 \%$ & $35.4 \%$ \\
\hline 2006 & 114 & $6.1 \%$ & $21.1 \%$ & $38.6 \%$ & $43.9 \%$ & $47.4 \%$ \\
\hline 2007 & 112 & $2.7 \%$ & $17.9 \%$ & $34.8 \%$ & $44.6 \%$ & $45.5 \%$ \\
\hline
\end{tabular}

Average

\begin{tabular}{|c|c|c|c|c|c|c|}
\hline $\begin{array}{c}\text { Overall UA } \\
\text { Engineering } \\
\text { Cohorts }\end{array}$ & $\begin{array}{c}\text { \# of } \\
\text { Participants }\end{array}$ & $\begin{array}{c}\text { Graduated in } \\
\text { 2 or Fewer } \\
\text { Years }\end{array}$ & $\begin{array}{c}\text { Graduated in } \\
\text { 3 or Fewer } \\
\text { Years }\end{array}$ & $\begin{array}{c}\text { Graduated in } \\
\text { 4 or Fewer } \\
\text { Years }\end{array}$ & $\begin{array}{c}\text { Graduated in } \\
\mathbf{5} \text { or Fewer } \\
\text { Years }\end{array}$ & $\begin{array}{c}\text { Graduated in } \\
\mathbf{6} \text { or Few er } \\
\text { Years }\end{array}$ \\
\hline 2001 & 406 & $1.0 \%$ & $6.4 \%$ & $21.7 \%$ & $35.7 \%$ & $40.1 \%$ \\
\hline 2002 & 400 & $0.0 \%$ & $2.8 \%$ & $14.0 \%$ & $32.0 \%$ & $39.5 \%$ \\
\hline 2003 & 422 & $0.7 \%$ & $3.6 \%$ & $16.6 \%$ & $35.8 \%$ & $42.2 \%$ \\
\hline 2004 & 463 & $0.4 \%$ & $4.3 \%$ & $15.6 \%$ & $34.6 \%$ & $41.3 \%$ \\
\hline 2005 & 487 & $0.6 \%$ & $3.3 \%$ & $16.4 \%$ & $33.7 \%$ & $39.2 \%$ \\
\hline 2006 & 619 & $1.1 \%$ & $4.4 \%$ & $20.4 \%$ & $38.0 \%$ & $41.8 \%$ \\
\hline 2007 & 599 & $0.5 \%$ & $3.3 \%$ & $21.0 \%$ & $38.4 \%$ & $42.9 \%$ \\
\hline
\end{tabular}




\section{Graduation Rates for Students Who Left the S-STEM Program}

Another group of students should also be considered when evaluating the results of this project. This group consists of those students who left the UA S-STEM project at some point by their own choice or because of not maintaining eligibility requirements. Overall, 20 students separated from the program over the 5.5 year project period. Of these 20, eight separated voluntarily. The separated students participated in many of the cohort activities. Therefore, it is possible that these activities played a role in their academic progress. Unfortunately, students who left UA were difficult to track, resulting in no data for those students. However, some students who left the UA S-STEM program stayed at UA and their progress was tracked. Table 7 shows the graduation rates for the students who separated from the program and graduated from UA in either engineering or another STEM discipline. Out of the 20 students who separated from the program, seven graduated from UA, six of those in STEM disciplines including three in engineering. These are worst-case numbers since they only represent those seven students who remained at UA.

Table 7. Graduation Rates For Participants Who Left The UA S-STEM Program

\begin{tabular}{|c|c|c|c|c|c|c|}
\hline & $\begin{array}{c}\text { \# of } \\
\text { Participants }\end{array}$ & $\begin{array}{c}\text { Graduated in } \\
\text { 2 or Few er } \\
\text { Years }\end{array}$ & $\begin{array}{c}\text { Graduated in } \\
\text { 3 or Few er } \\
\text { Years }\end{array}$ & $\begin{array}{c}\text { Graduated in } \\
\text { 4 or Fewer } \\
\text { Years }\end{array}$ & $\begin{array}{c}\text { Graduated in } \\
\text { 5 or Few er } \\
\text { Years }\end{array}$ & $\begin{array}{c}\text { Graduated in } \\
\text { 6 or Fewer } \\
\text { Years }\end{array}$ \\
\hline $\begin{array}{c}\text { Original S-STEM } \\
\text { Freshman Cohort }\end{array}$ & 13 & 0 & 0 & 0 & 0 & 1 \\
\hline & & $0.0 \%$ & $0.0 \%$ & $0.0 \%$ & $0.0 \%$ & $7.7 \%$ \\
\hline \hline Transfer Students & 7 & 0 & 0 & 1 & 2 & 2 \\
\hline \hline Overall & 20 & $0.0 \%$ & $0.0 \%$ & $14.3 \%$ & $28.6 \%$ & $28.6 \%$ \\
\hline & & 0 & 0 & 1 & 2 & 3 \\
\hline
\end{tabular}

\begin{tabular}{|c|c|c|c|c|c|c|}
\hline & $\begin{array}{c}\text { \# of } \\
\text { Participants }\end{array}$ & $\begin{array}{c}\text { Graduated in } \\
\text { 2 or Fewer } \\
\text { Years }\end{array}$ & $\begin{array}{c}\text { Graduated in } \\
\text { 3 or Few er } \\
\text { Years }\end{array}$ & $\begin{array}{c}\text { Graduated in } \\
\text { 4 or Fewer } \\
\text { Years }\end{array}$ & $\begin{array}{c}\text { Graduated in } \\
\text { 5 or Fewer } \\
\text { Years }\end{array}$ & $\begin{array}{c}\text { Graduated in } \\
\text { 6 or Few er } \\
\text { Years }\end{array}$ \\
\hline $\begin{array}{c}\text { Original S-STEM } \\
\text { Freshman Cohort }\end{array}$ & 13 & 0 & 0 & 0 & 1 & 3 \\
\hline & & $0.0 \%$ & $0.0 \%$ & $0.0 \%$ & $7.7 \%$ & $23.1 \%$ \\
\hline \hline Transfer Students & 7 & 0 & 0 & 2 & 3 & 3 \\
\hline \hline Overall & 20 & $0.0 \%$ & $0.0 \%$ & $0.0 \%$ & $28.6 \%$ & $42.9 \%$ \\
\hline & & 0 & 0 & 2 & 4 & 6 \\
\hline
\end{tabular}

If the data in Table 7 (students that graduated but not as part of the UA S-STEM program) is combined with those students who graduated as part the UA S-STEM program (data from Table 6), the results are very positive and are shown in Table 8. Fifty percent of the original UA S-STEM freshman cohort graduated in engineering. Similarly, 50\% of the transfer students that participated in the UA S-STEM program graduated in engineering. In both cases, these graduation rates are significantly higher than any comparable group at UA, as shown in Table 6 where the average graduation rate in six or fewer years for UA freshman engineering cohorts from $2001-2007$ is $39.6 \%$ and for UA engineering transfer cohorts is $45.1 \%$. If one considers all STEM disciplines, the graduation rate for the UA S-STEM freshman cohort rises to $58.3 \%$ and for the transfer participants to $60.0 \%$. 
Although not shown in Table 8, it should be noted that one other student from the UA S-STEM program graduated in a non-STEM discipline bringing the total graduation rate to $61.8 \%$.

Table 8. Graduation Rates For All UA S-STEM Program Participants

\begin{tabular}{|c|c|c|c|c|c|c|}
\hline \multicolumn{7}{|c|}{ Engineering Graduates } \\
\hline & $\begin{array}{c}\text { \# of } \\
\text { Participants }\end{array}$ & $\begin{array}{c}\text { Graduated in } \\
2 \text { or Fewer } \\
\text { Years }\end{array}$ & $\begin{array}{c}\text { Graduated in } \\
3 \text { or Fewer } \\
\text { Years }\end{array}$ & $\begin{array}{c}\text { Graduated in } \\
4 \text { or Fewer } \\
\text { Years }\end{array}$ & $\begin{array}{c}\text { Graduated in } \\
5 \text { or Fewer } \\
\text { Years }\end{array}$ & $\begin{array}{c}\text { Graduated in } \\
6 \text { or Fewer } \\
\text { Years }\end{array}$ \\
\hline \multirow[t]{2}{*}{$\begin{array}{l}\text { Original S-STEM } \\
\text { Freshman Cohort }\end{array}$} & 24 & 0 & 0 & 4 & 10 & 12 \\
\hline & & $0.0 \%$ & $0.0 \%$ & $16.7 \%$ & $41.7 \%$ & $50.0 \%$ \\
\hline \multirow[t]{2}{*}{ Transfer Students } & 10 & 0 & 1 & 4 & 5 & 5 \\
\hline & & $0.0 \%$ & $10.0 \%$ & $40.0 \%$ & $50.0 \%$ & $50.0 \%$ \\
\hline \multirow[t]{2}{*}{ Overall } & 34 & 0 & 1 & 8 & 15 & 17 \\
\hline & & $0.0 \%$ & $2.9 \%$ & $23.5 \%$ & $44.1 \%$ & $50.0 \%$ \\
\hline
\end{tabular}

\begin{tabular}{|c|c|c|c|c|c|c|}
\hline & $\begin{array}{c}\text { \# of } \\
\text { Participants }\end{array}$ & $\begin{array}{c}\text { Graduated in } \\
\text { 2 or Fewer } \\
\text { Years }\end{array}$ & $\begin{array}{c}\text { Graduated in } \\
\text { 3 or Few er } \\
\text { Years }\end{array}$ & $\begin{array}{c}\text { Graduated in } \\
\text { 4 or Fewer } \\
\text { Years }\end{array}$ & $\begin{array}{c}\text { Graduated in } \\
\text { 5 or Fewer } \\
\text { Years }\end{array}$ & $\begin{array}{c}\text { Graduated in } \\
\text { 6 or Few } \\
\text { Years }\end{array}$ \\
\hline $\begin{array}{c}\text { Original S-STEM } \\
\text { Freshman Cohort }\end{array}$ & 24 & 0 & 0 & 4 & 12 & 14 \\
\hline & & $0.0 \%$ & $0.0 \%$ & $16.7 \%$ & $50.0 \%$ & $58.3 \%$ \\
\hline \hline Transfer Students & 10 & 0 & 1 & 5 & 6 & 6 \\
\hline \hline Overall & 34 & $0.0 \%$ & $10.0 \%$ & $50.0 \%$ & $60.0 \%$ & $60.0 \%$ \\
\hline & & 0 & 1 & 9 & 18 & 20 \\
\hline
\end{tabular}

It is also interesting to track graduation status of the UA S-STEM students vs. their starting position in the mathematics sequence as shown in Table 9. The data in Table 9 is applicable to only the original UA S-STEM freshman cohort. This data details the number of participants that graduated within and after leaving the UA SSTEM program and presents these numbers as percentages of the total number of participants in the same math group. It is interesting to note that all six students who entered the program Calculus-ready graduated from UA, and five of the six graduated in a STEM discipline. However, only 50\% of those not Calculus-ready graduated either as part of or after they left the UA S-STEM project. The data in Table 9 includes graduates from any discipline. 
Table 9. Graduation Status vs. Starting Math Course For The Original UA S-STEM Students

\begin{tabular}{|c|c|c|c|c|c|c|c|c|}
\hline \multirow[t]{2}{*}{ Starting Math Course } & \multicolumn{2}{|c|}{$\begin{array}{c}\text { UA S-STEM } \\
\text { Freshman Cohort }\end{array}$} & \multicolumn{2}{|c|}{$\begin{array}{c}\text { \# Graduates } \\
\text { (Within Program) }\end{array}$} & \multicolumn{2}{|c|}{$\begin{array}{l}\text { \# Graduates } \\
\text { (Left Program) }\end{array}$} & \multicolumn{2}{|c|}{ Total } \\
\hline & $\#$ & $\%$ & $\#$ & $\%$ & $\#$ & $\%$ & \# & $\%$ \\
\hline Calculus I or Higher & 6 & $25.00 \%$ & 4 & $66.67 \%$ & 2 & $33.33 \%$ & 6 & $100.00 \%$ \\
\hline Below Calculus I & 18 & $75.00 \%$ & 7 & $38.89 \%$ & 2 & $11.11 \%$ & 9 & $50.00 \%$ \\
\hline Total & 24 & $100.00 \%$ & 11 & $45.83 \%$ & $4^{*}$ & $16.67 \%$ & 15 & $62.50 \%$ \\
\hline $\begin{array}{l}\text { All Transfer Students Started in Calculus II } \\
\text { or Higher }\end{array}$ & & & & & & & & \\
\hline * 3 in STEM disciplines including 1 in CE & & & & & & & & \\
\hline Details for Below Calculus I & & & & & & & & \\
\hline 1 Course Below Calculus I & 7 & $38.89 \%$ & 3 & $42.86 \%$ & 1 & $14.29 \%$ & 4 & $57.14 \%$ \\
\hline 2 Courses Below Calculus I & 8 & $44.44 \%$ & 3 & $37.50 \%$ & 1 & $12.50 \%$ & 4 & $50.00 \%$ \\
\hline 3 Courses Below Calculus I (remedial math) & 3 & $16.67 \%$ & 1 & $33.33 \%$ & 0 & $0.00 \%$ & 1 & $33.33 \%$ \\
\hline Total & 18 & $100.00 \%$ & 7 & $38.89 \%$ & 2 & $11.11 \%$ & 9 & $50.00 \%$ \\
\hline
\end{tabular}

Comparative data for UA freshman engineering cohorts is shown in Table 10. Again, the data is presented as percentages of the total size of each math group, not the total cohort size. All students who graduated as of Summer 2013 are included in Table 10. This is in contrast to providing graduation rates within a sliding timeframe as was done in Table 6. Considering both those students who completed the UA S-STEM program and those who left the program, $100 \%$ of the Calculus-ready participants graduated compared to the average of $59.7 \%$ for the engineering cohorts. Even if one only considers the UA-STEM participants that graduated as part of the UA SSTEM program, the $66.7 \%$ (four out of six) graduation rate of those who were Calculus-ready is significantly higher than any UA engineering cohort.

Obviously, students that enter engineering not Calculus-ready have a more difficult time graduating with an engineering degree. The data in Table 10 substantiate that fact as the average graduation rate for the engineering cohorts for those students who were not Calculus-ready was only 26.2\%. However, for the UA S-STEM participants, the graduation rate was $38.9 \%$ for those completing the S-STEM program and $50.0 \%$ overall. This is a significant improvement indicating that the activities undertaken to support and improve the math skills of the participants were successful. Such an improvement, if effected across the entire UA College of Engineering, would result in an overall $48.4 \%$ improvement in graduation rate of students who are not Calculus-ready when they start their studies. 
Table 10. Graduation Data vs. Starting Math Courses For General Engineering Cohorts (UA, 2014c)

\begin{tabular}{|c|c|c|c|c|c|}
\hline \multirow{2}{*}{ Year } & \multirow{2}{*}{ Starting Math Course } & \multirow[b]{2}{*}{ \# } & \multirow[b]{2}{*}{$\%$} & \multicolumn{2}{|c|}{ Graduated in Engineering } \\
\hline & & & & \# & $\%$ \\
\hline \multirow[t]{3}{*}{2001} & Calculus I or Higher & 102 & $36.04 \%$ & 57 & $55.88 \%$ \\
\hline & Below Calculus I & 181 & $63.96 \%$ & 42 & $23.20 \%$ \\
\hline & Total & 283 & $100.00 \%$ & 99 & $34.98 \%$ \\
\hline \multirow[t]{3}{*}{2002} & Calculus I or Higher & 132 & $40.87 \%$ & 79 & $59.85 \%$ \\
\hline & Below Calculus I & 191 & $59.13 \%$ & 52 & $27.23 \%$ \\
\hline & Total & 323 & $100.00 \%$ & 131 & $40.56 \%$ \\
\hline \multirow[t]{3}{*}{2003} & Calculus I or Higher & 122 & $37.77 \%$ & 81 & $66.39 \%$ \\
\hline & Below Calculus I & 201 & $62.23 \%$ & 63 & $31.34 \%$ \\
\hline & Total & 323 & $100.00 \%$ & 144 & $44.58 \%$ \\
\hline \multirow[t]{3}{*}{2004} & Calculus I or Higher & 152 & $42.70 \%$ & 93 & $61.18 \%$ \\
\hline & Below Calculus I & 204 & $57.30 \%$ & 54 & $26.47 \%$ \\
\hline & Total & 356 & $100.00 \%$ & 147 & $41.29 \%$ \\
\hline \multirow[t]{3}{*}{2005} & Calculus I or Higher & 156 & $39.90 \%$ & 95 & $60.90 \%$ \\
\hline & Below Calculus I & 235 & $60.10 \%$ & 64 & $27.23 \%$ \\
\hline & Total & 391 & $100.00 \%$ & 159 & $40.66 \%$ \\
\hline \multirow[t]{3}{*}{2006} & Calculus I or Higher & 275 & $54.46 \%$ & 151 & $54.91 \%$ \\
\hline & Below Calculus I & 230 & $45.54 \%$ & 56 & $24.35 \%$ \\
\hline & Total & 505 & $100.00 \%$ & 207 & $40.99 \%$ \\
\hline \multirow[t]{3}{*}{2007} & Calculus I or Higher & 246 & $50.51 \%$ & 145 & $58.94 \%$ \\
\hline & Below Calculus I & 241 & $49.49 \%$ & 57 & $23.65 \%$ \\
\hline & Total & 487 & $100.00 \%$ & 202 & $41.48 \%$ \\
\hline Average & Calculus I or Higher & $59.72 \%$ & & & \\
\hline Average & Below Calculus I & $26.21 \%$ & & & \\
\hline
\end{tabular}

\section{B. Qualitative Results}

While retention and graduation rates provide quantitative data for evaluation of the project, student activities and accomplishments while participating in the UA S-STEM program, student feedback, and observations from project administrators serve as qualitative evaluation metrics. The following is a list of notable accomplishments by the students who completed the UA S-STEM project. This data was collected via surveys, student interviews, and review of student records.

Notable student accomplishments:

- $\quad$ Seven (7) students participated in the UA Cooperative Education Program.

- $\quad$ One (1) student participated in a Research Experiences for Undergraduates (REU) program in California during Summer 2009 and Summer 2010.

- $\quad$ One (1) participant was recognized as the ECE Sophomore Meritorious Award Winner in Spring 2009, the ECE Junior Meritorious Award winner in Spring 2010, and the ECE Senior Meritorious Award winner in Spring 2011 having maintained an overall GPA of 4.00/4.00.

- $\quad$ At least five (5) of the graduates are in graduate school or have completed a graduate degree; one (1) graduate is a Ph.D. student at Georgia Tech (only twelve (12) students surveyed). 
- $\quad$ At least seven (7) graduates are employed full-time as engineers in their respective discipline (only twelve (12) students surveyed).

- $\quad$ One (1) participant served as President of the UA IEEE student chapter.

- $\quad$ One (1) participant was a member of the UA IEEE SoutheastCon Hardware Competition Team, placing $6^{\text {th }}$ out of 54 teams at the competition in Orlando, Florida in Spring 2012.

According to student feedback, much of this progress can be attributed to the peer study groups, mentoring, and tutoring created as part of the project. The financial assistance was also recognized as an integral part for these students. Student testimonials are presented below supporting these conclusions.

"I wanted to personally say thank you so much for the opportunities that you have helped me receive through the SSTEM project. It really helped me financially ..."

“...the classes that myself and the other students had together as a group freshman year created bonds and study partners that lasted throughout college."

Finally, some observations and conclusions from project administrators are presented. These observations were developed after 5.5 years coordinating the project, interacting with the student participants, conducting student interviews and compiling survey results, and interviews with project administrators for similar projects at other institutions.

- $\quad$ Students felt that their cohort study groups were a significant part of this project and directly contributed to their success.

- $\quad$ Recruiting of transfer students was very time consuming. In fact, if student progress is evaluated after the end of each semester, it is virtually impossible to recruit new participants between the Fall and Spring semesters. This results in attrition that cannot be replaced in the Spring semester. Also, adding new participants to the cohort group each semester tends to erode the benefits of the cohort itself.

- $\quad$ Student feedback indicates that undergraduates appreciated mentoring and tutoring from undergraduate upperclassmen more so than from graduate students. There seemed to be an element of intimidation when interacting with graduate students.

- The mentoring success of this project helped in the institutionalization of a mentoring program within the UA College of Engineering. Specifically, a new program, called Mentor UPP: Undergraduate Peer Partnering, has been created to facilitate peer mentoring. In the Mentor UPP program, undergraduates at the junior and senior levels serve as peer mentors to freshmen, sophomores, and transfer students. As lower-level undergrads advance, they are asked to give back by serving as mentors in the program. Faculty also serve as mentors to groups of undergrads, and plans include the use of alumni mentors for upper-level undergraduates (UA, 2014b).

- $\quad$ Transfer students need special programs to help them acclimate to their new environment.

- $\quad$ Students need academic standards and hands-on project administration. Without well-stated academic goals and visible project administration, some students will take advantage of the "free" scholarship money without regard to their own progress toward a degree. The academic standards must be challenging but not impossible. Students should be held accountable for their academic performance, but that must be balanced with constructive support. A quality balance between expectations and performance was obtained by implementing an "academic warning" status for students. If goals were not met, students were not immediately dismissed from the project. Instead, they were placed on academic warning, individualized goals were created for them, and they were given one more semester to show progress. This "two strikes and you're out" policy achieved two things. First, it had some teeth so students knew they had to perform academically to continue in the program. Secondly, it showed some flexibility and fairness, and feedback from students indicated they appreciated the fairness of the process. 
- $\quad$ The establishment of efficient procedures needed to perform the administrative tasks associated with this type of project is critical. Necessary tasks included review of the academic status of all students each semester, allocation of scholarships each semester, recruiting replacements, verification of financial need, academic advising, and coordination of student support services like hiring tutors, lining up mentors, and organizing extracurricular activities. These tasks required coordination with several offices across campus and should not be taken lightly, especially considering the dynamic nature of student activities (dropping and adding courses without permission, changing majors without consulting an advisor, etc.). This infrastructure played a significant role in project success and failure.

\section{CONCLUSIONS AND FUTURE WORK}

The research reported in this paper contributes to the knowledge base regarding the effectiveness of learning communities for increasing retention and graduation rates in STEM disciplines, specifically in this case engineering disciplines. This project was designed to address three significant threats to the academic success of engineering students: financial difficulties, math deficiencies, and a lack of sense of belonging to the engineering community. Scholarships were made available to address the financial issues; tutors, mentors, study groups, and a "freshman-to-sophomore bridge" summer program were provided to address math deficiencies; cohort engineering courses, active learning techniques involving field trips and hands-on projects, required group meetings, required study sessions, peer mentoring, dedicated study space, and dedicated faculty advisors were used to promote a sense of community and belonging as well as improved study habits.

The resulting retention and graduation rates of the participants completing the project are higher than most comparable cohort groups at the same institution. Additional analysis was performed on those students who partially completed the project, leaving before completion either voluntarily or due to failing to meet one or more continuing eligibility requirements. When combined with those who completed the project, retention and graduation rates are significantly higher than comparable cohort groups. Qualitative student feedback indicates that scholarships, cohort course sections, study groups, and peer mentoring/peer relationships played a significant role in student successes.

The next step is to continue institutionalization of many aspects of this project. While Mentor UPP is one example of institutionalization resulting from this project, there are opportunities for others. Specifically, more work is needed to help transfer students acclimate to a new institution and to succeed. Scholarship and mentoring programs dedicated to transfer students are in short supply and are desperately needed. More research is needed to study relationships among math starting points and graduation and retention rates. For those students who need several pre-Calculus courses, there needs to be courses that will count toward the degree while the student is prepping for Calculus I. This can be solved in many cases by decoupling some courses from the Calculus sequence, specifically courses that have little dependence upon the Calculus material but use Calculus as a prerequisite "filter" for scholastic maturity. Finally, more research is needed to investigate non-academic reasons for "drop out" among engineering students.

\section{REFERENCES}

1. Besterfield-Sacre, M., \& Atman, C. J., \& Shuman, L. (1997). Characteristics of Freshman Engineering Students: Models for Determining Student Attrition in Engineering. Journal of Engineering Education, 86(2), 139-149.

2. Clough, G. W. (2006). Reforming Engineering Education. The Bridge. 36(2), 3.

3. Coston, C. T. M., \& Lord, V. B., \& Monell, J. S. (2013). Improving the Success of Transfer Students: Responding to Risk Factors. Learning Communities Research and Practice, 1(1), Article 11. Retrieved from http://washingtoncenter.evergreen.edu/lcrpjournal/vol1/iss1/11.

4. Federal Student Aid. (2014). Free Application for Federal Student Aid. Retrieved from https://fafsa.ed.gov/.

5. Gates Jr, J. \& Mirkin, C. (2012). Encouraging STEM Students is in the National Interest. The Chronicle of Higher Education. Retrieved from http://chronicle.com/article/Encouraging-STEM-Students-Is/132425/. 
6. Gilmer, T. C. (2007). An Understanding of the Improved Grades, Retention, and Graduation Rates of STEM Majors as the Academic Investment in Math and Science (AIMS) Program of Bowling Green State University (BGSU). Journal of STEM Education. 8(1, 2), 11-21.

7. Grimm, M. (2005). Work in progress - An Engineering Bridge Program - The Foundation for Success for Academically At-Risk Students. Proceedings of the $35^{\text {th }}$ ASEE/IEEE Frontiers in Education Conference, Indianapolis, IN.

8. Grose, T. K. (2012). 10,000 Challenge. ASEE Prism. Retrieved from http://www.prismmagazine.org/feb12/feature_02.cfm.

9. Hanover Research. (2011). Innovative Practices for Improving Student Performance in College Level Mathematics. Retrieved from http://www.mybrcc.edu/intranet/attachments/article/110/Innovative\%20Practices\%20for\%20Improving\%2 0Student \%20Performance\%20in\%20College\%20Level\%20Mathematics.pdf.

10. Hartman, H., \& Hartman, M. (2006). Leaving Engineering: Lessons from Rowan University's College of Engineering. Journal of Engineering Education, 95(1), 49-59.

11. Herzog, S. (2003). Measuring Determinants of Student Return vs. Transfer vs. Stopout, vs. Dropout: A First-to-Second year Analysis of New Freshmen. Paper presented to the California Association for Institutional Research. Retrieved from http://www.cair.org/conferences/CAIR2003/SergeHerzogBPComp.pdf.

12. Knight, D. W., \& Carlson, L. E., \& Sullivan, J. F. (2003). Staying in Engineering: Impact of a Hands-On, Team-Based, First-Year Projects Course on Student Retention. Proceedings of the 2003 American Society for Engineering Education Annual Conference \& Exposition. Retrieved from http://itll.colorado.edu/images/uploads/about_us/publications/Papers/ASEE\%2003\%20Retention\%20GEE N\%201400\%20Proceedings.pdf.

13. Lichtenstein, G., \& McCormick, A. C., \& Sheppard, S., \& Puma, J. (2010). Comparing The Undergraduate Experience Of Engineers To All Other Majors: Significant Differences Are Programmatic. Journal of Engineering Education. 99(4), 305-317.

14. Litzler, E., \& Young, J. (2012). Understanding the Risk of Attrition in Undergraduate Engineering: Results from the Project to Assess Climate in Engineering. Journal of Engineering Education. 101(2), 319-345.

15. Marra, R. M., \& Rodgers, K. A., \& Shen, D., \& Bogue, B. (2012). Leaving Engineering: A Multi-Year Single Institution Study. Journal of Engineering Education. 101(1), 6-27.

16. Matthews, M. (2012). Keeping students in engineering: A research-to-practice brief. American Society for Engineering Education. Retrieved from http://www.asee.org/retention-project/keeping-students-inengineering-a-research-guide-to-improving-retention.

17. Matusovich, H. M., \& Streveler, R. A., \& Miller, R. (2010). How They See Themselves: Students who identify with engineering persist in the field. ASEE Prism.

18. Moore, C. \& Shulock, N. (2009). Student Progress Toward Degree Completion: Lessons from the Research Literature. Institute for Higher Education Leadership and Policy, p. 4, Retrieved from http://www.csus.edu/ihelp/PDFs/R_Student_Progress_Toward_Degree_Completion.pdf.

19. National Science Foundation, Science and Engineering Indicators: 2008 (NSB 08-01), Retrieved from http://www.nsf.gov/statistics/seind08/pdf/front.pdf.

20. National Science Foundation Scholarships in Science, Technology, Engineering, and Math (S-STEM) Program. (2014). Retrieved from http://www.nsf.gov/funding/pgm_summ.jsp?pims_id=5257\&org=DUE.

21. Ohland., M., \& Sheppard, S., \& Lichtenstein, G., \& Eris, O., \& Chachra, D., \& Layton, R. (2008). Persistence, Engagement, and Migration in Engineering Programs. Journal of Engineering Education. 97(3), 259-278.

22. Parker, M. (2005). Placement, Retention, and Success: A Longitudinal Study of Mathematics and Retention. The Journal of General Education, 54(1), 22-40.

23. Rutar, T., \& Mason, G. (2005). A Learning Community of Freshman Design, Freshman Graphics, and High School Technology Students: Description, Projects, and Assessment. Journal of Engineering Education. 94(2), 245-254.

24. Scalise, A., \& Besterfield-Sacre, M., \& Shuman, L., \& Wolfe, H. (2000). First Term Probation: Models for Identifying High Risk Students. Proceedings of the $30^{\text {th }}$ ASEE/IEEE Frontiers in Education Conference, Kansas City, MO. 
25. Seymour, E. Y., \& Hewitt, N. M. (1997). Talking About Leaving: Why Undergraduates Leave the Sciences, Colorado: Westview Press.

26. Terenzini, P. T., \& Cabrera, A. F., \& Colbeck, C. L., \& Parente, J. M., \& Bjorklund, S. A. (2001). Collaborative Learning vs. Lecture/Discussion: Students' Reported Learning Gains. Journal of Engineering Education. 90(1), 123-130.

27. The University of Alabama. (2014a). Retrieved from http://cost.ua.edu/undergraduate-budget.html.

28. The University of Alabama College of Engineering Mentor UPP Program. (2014b). Retrieved from http://mentoring.eng.ua.edu/.

29. The University of Alabama Office of Institutional Research and Assessment. (2014c). First-Time, FullTime Undergraduate Engineering Cohorts by First Math Course and Graduation in Engineering. Internal report.

30. The University of Alabama Office of Institutional Research and Assessment. (2012, updated 2014d). Engineering Graduation and Retention Rates. Internal report.

31. The University of Alabama Office of Institutional Research and Assessment. (2010, updated 2014e). Engineering Graduation Rate of Transfer Students. Internal report.

32. Tinto, V. (1975). Dropout from Higher Education: A Theoretical Synthesis of Recent Research. Review of Educational Research. 45(1), 89-125.

33. Tinto, V. (2006). Research and Practice of Student Retention: What Next? Journal of College Student Retention. 8(1), 1-19.

34. Veenstra, C. P. (2010). The Diversity of STEM Majors and a Strategy for Improved STEM Retention. Veenstra and Associates, Retrieved from https://static.squarespace.com/static/51fafa0ee4b0d906af53ce83/51fb1157e4b0951c6cc91d03/51fb1157e4b 0951c6cc91d08/1325119321937/Diversity-of-STEM-Majors.pdf.

35. Zhao, C. \& Kuh, G. D. (2004). Adding Value: Learning Communities and Student Engagement. Research in Higher Education. 45(2), 115-138. 